\title{
Utilization of the chlorophyll $a$ fluorescence technique as a tool for selecting tolerant species to environments of high irradiance
}

\author{
José Francisco de Carvalho Gonçalves* and Ulysses Moreira dos Santos Júnior
}

Laboratório de Fisiologia e Bioquímica Vegetal, Instituto Nacional de Pesquisas da Amazônia, CP 478, 69011-970, Manaus, AM, Brasil; *Corresponding author: jfc@inpa.gov.br.

Received: 06/07/2005, Accepted: 15/10/2005

We examine the hypothesis that the chlorophyll $a$ fluorescence technique can be an efficient tool to support the selection of species adapted to high irradiance and therefore, suitable for use in initial rehabilitation projects of degraded areas. The experiment was conducted at the Pedro de Moura Operational Base, Amazonas, Brazil. The fluorescence transients were obtained using a portable fluorometer for leaves of Bombacopsis macrocalyx (Bm), Eugenia cumini (Ec), Iryanthera macrophyla $(\mathrm{Im})$ and Senna reticulata $(\mathrm{Sr})$, which were subjected to high irradiance between 12:00 am and 1:00 p.m. Using the OJIP test, the following were calculated: performance index $\left(P I_{A B S}\right)$, density of reaction centres per cross section (RC/CS), maximum efficiency of photosystem II $\left(\phi_{P_{o}}\right)$, and probability of energy excitation $\left(\psi_{o}\right)$ or that an absorbed photon $\left(\phi_{E O}\right)$ moves an electron beyond quinone A. The highest value of $P I_{A B S}$ was found in $E c(0.40)$ while the lowest values were found in $B m(0.08)$ and $I m$ (0.06). These low values of $P I_{A B S}$ in $B m$ and $I m$ were a result of the low values for RC/CS (121 for $B m ; 142$ for $\left.I m\right)$ and $\phi_{P o}(0.50$ for $B m ; 0.48$ for $I m)$ when compared to the values in $E c\left(\mathrm{RC} / \mathrm{CS}=303 ; \phi_{P o}=0.72\right)$ and $S r\left(\mathrm{RC} / \mathrm{CS}=326 ; \phi_{P_{o}}=0.73\right)$. It was also observed that in $S r$ the decrease in $P I_{A B S}$ when compared with $E c$ resulted from a low value of $\psi_{o}$, which was $32 \%$ lower than the value found in $E c$. Regarding the $\mathrm{PI}_{\mathrm{ABS}}$ per plant, $E c$ had the largest number of individuals with high performance while $\mathrm{Im}$ and $B m$ had the largest numbers of individuals with low performance. In conclusion, the chlorophyll $a$ fluorescence technique enabled the evaluation of the photochemical performance of plants in the field, in turn permitting the selection of species most suitable for rehabilitation of degraded areas.

Key words: degraded areas, energy flux, performance index.

Utilização da técnica de fluorescência da clorofila $a$ como uma ferramenta para a seleção de espécies tolerantes a ambientes de alta irradiância: Neste trabalho, examinamos a hipótese de que a técnica de fluorescência da clorofila $a$ possa ser uma ferramenta eficiente para dar suporte à seleção de espécies adaptadas à alta irradiância e, entretanto, aptas a serem utilizadas em plantios de recuperação de áreas degradadas. Realiizou-se o experimento na Base de Operações Geólogo Pedro de Moura, Amazonas, Brasil. Os transientes de fluorescência foram obtidos utilizando-se um fluorômetro portátil, em folhas de Bombacopsis macrocalyx (Bm), Eugenia cumini (Ec), Iryanthera macrophyla (Im) e Senna reticulata (Sr) submetidas a alta irradiância, no período entre 12 e 13h. A partir do teste OJIP, calcularam-se: o índice de desempenho $\left(P I_{A B S}\right)$, a densidade de centros de reação por seção transversal (RC/CS), a eficiência máxima do fotossistema II $\left(\phi_{P o}\right)$ e a probabilidade da energia de excitação $\left(\psi_{o}\right)$ ou de um fóton absorvido $\left(\phi_{E o}\right)$ mover um elétron após a quinona A. Observou-se maior valor de $P I_{A B S} \mathrm{em} E c$ $(0,40)$, e, os menores, em $B m(0,08)$ e $\operatorname{Im}(0,06)$. Esses baixos valores resultaram dos baixos valores de RC/CS $(121$ para $B m$; 142 para $I m)$ e $\phi_{P_{o}}(0,50$ para $B m ; 0,48$ para $I m)$ quando comparados com os exibidos por $E c\left(\mathrm{RC} / \mathrm{CS}=303 ; \phi_{P_{o}}=0,72\right)$ e $S r$ $\left(\mathrm{RC} / \mathrm{CS}=326 ; \phi_{P_{o}}=0,73\right)$. Observou-se, ainda, que em $S r$, a diminuição de seu $P I_{A B S}$ quando comparada com $E c$, resultou do baixo valor de $\psi_{o}$, no qual $S r$ apresentou $32 \%$ menor que $E c$. Quanto ao $P I_{A B S}$ por planta, $E c$ revelou o maior número de indivíduos com alto desempenho, e $I m$ e $B m$, o maior número de indivíduos com baixo desempenho. Conclui-se, portanto, que, por meio da técnica da fluorescência da clorofila $a$, foi possível diagnosticar o desempenho fotoquímico das plantas no campo, selecionando as espécies mais aptas à recuperação de áreas degradadas.

Palavras-chave: áreas degradadas, fluxo energético, índice de desempenho. 
Abbreviations: $A B S$ - absorption flux; $\mathrm{CS}$ - cross section; $D I_{0}$ - dissipation flux; $E T_{0}$ - electron transport flux; $F_{m}$ maximal fluorescence level; $F_{0}$ - minimal fluorescence level; $F_{v}$ - maximal variable fluorescence; $\phi_{D o}$ - maximum quantum yield of non-photochemical de-excitation; $\phi_{E o}$ - probability that an absorbed photon moves an electron beyond $\mathrm{Q}_{\mathrm{A}} ; \phi_{P_{o}}$ - maximum quantum yield of primary photochemistry; $\psi_{o}$ probability that a trapped exciton moves an electron beyond $\mathrm{Q}_{\mathrm{A}}{ }^{-} ; P I_{A B S}$ - performance index; PS II - photosystem II; $\mathrm{Q}_{\mathrm{A}}$ - primary quinone electron acceptor of PS II; $Q_{B}$ - secondary quinone electron acceptor of PS II; RC - reaction centre; $T R_{0}$ - energy flux for trapping.

\section{INTRODUCTION}

In the Amazon forest, human activities like deforestation, mining, logging and agricultural activities have caused significant changes in the forest ecosystems and consequently, have led to advanced degradation of the land (Fearnside, 1999, 2002; Laurance et al., 2002; Brandão et al., 2005). Among the major impacts on the forest are removal of forest cover, changes in the physical, chemical and microbiological relationships of the soils, and significant alteration of microclimates (Parrotta et al., 1997; Parrotta and Knowles, 1999). In short, human activities create an imbalance in the soil-plant-atmosphere continuum, as can be seen in the loss of forest cover, leading to microclimatic changes mainly involving significant increases in irradiance in the environment. Under these new conditions of light, the plants' success of establishment in the field depends upon the ability of different species to efficiently use and capture light. A plant's strategic adaptation to these conditions of high irradiance can be determined by the optimization of light energy use, which is dictated by the thermodynamic demand for a decrease in entropy in the reaction centres, particularly in photosystem II (PS II). A plant's ability to adapt to stressful environments is inherent. Nonetheless, it is necessary to select species capable of using excess light energy in the photosynthetic processes, which can result in greater accumulation of biomass. In this respect, the understanding of the physiological, biochemical and molecular processes used by plants in response to increases in irradiance can be an important factor in the selection of species suitable for reforestation, and consequently in determining the success of forest plantations.

Among the techniques utilized to study the changes that affect the photosynthetic apparatus and its working efficiency under different environmental conditions, the chlorophyll a fluorescence technique is of particular significance (Gonçalves et al., 2001). The analysis of chlorophyll $a$ fluorescence emitted by PS II is a quick, easy and nondestructive tool for screening a plant's photosynthetic performance, providing precise and objective data with regard to photochemical efficiency and the processes of nonphotochemical de-excitation involved in the conversion of light energy under different conditions (Clark et al., 2000; Maxwell and Johnson, 2000; Misra et al., 2001; Hermans et al., 2003). Under conditions of high irradiance, PS II is recognizably the first protein complex to exhibit damage. For this reason, the study of the structural and functional behavior of PS II can reveal the primary effects of stress caused by excess irradiance on plants.

Our hypothesis is that the chlorophyll $a$ fluorescence technique can be an efficient tool to support the selection of species adapted to high irradiance and therefore, suitable for use in initial rehabilitation projects of degraded areas. Therefore, the objective of this study was to investigate the interspecies variations in chlorophyll fluorescence in four tree species by evaluating their efficiency in capture and use of light energy in environments of high irradiance through the analysis of changes in the parameters of chlorophyll $a$ fluorescence.

\section{MATERIAL AND METHODS}

Study area and species investigated: The experiment was carried out in August 2002 and conducted in a degraded area located in the Pedro de Moura Operational Base in the state of Amazonas, Brazil ( $4^{0} 53^{\prime} \mathrm{S}$ e $\left.65^{0} 11^{\prime} \mathrm{W}\right)$. According to the Koppem classification, the climate of the region is an Afi type, typically tropical with annual precipitation greater than $3000 \mathrm{~mm}$. The species selected for the experiment were Bombacopsis macrocalyx, Eugenia cumuni, Iryanthera macrophylla, and Senna reticulata. The seedlings originated in the seeds of selected trees taken from the region close to the Urucu River, where they were germinated in washed sand and immediately planted in polyethylene bags of $3 \mathrm{~kg}$ capacity. The seedlings were watered daily and subjected to a period of acclimatization by being exposed to various levels and luminosity until they reached the last stage, when they were exposed to full sunlight. In the field, seedlings of about four months old were planted with a spacing of $1 \times 1 \mathrm{~m}$ at a depth $45 \mathrm{~cm}$. Each seedling was fertilized with $160 \mathrm{~g}$ of NPK (10-30-10) and $40 \mathrm{~g}$ of magnesium sulfate. 
Chlorophyll a fluorescence measurements: The determination of chlorophyll $a$ fluorescence was carried out using a portable fluorometer (Plant Efficiency Analyzer-MK2- 9600 Hansatech, Norfolk, UK) on completely expanded leaves of appropriate phytosanitary condition. The data were collected in July 2004 between 12:00 p.m. and 1 p.m. (irradiance $=2000$ $\left.-2300 \mu \mathrm{mol} . \mathrm{m}^{-2} \mathrm{~s}^{-1}\right)$ using 10 plants per species. The selected leaves were subjected to a 20 minutes period of adaptation to darkness, sufficient for complete oxidation of the reaction centres. The leaves were then exposed to a pulse of saturated light at an intensity of $2250 \mu \mathrm{mol} \cdot \mathrm{m}^{-2} \cdot \mathrm{s}^{-1}$ and a wavelength of $650 \mathrm{~nm}$ for $5 \mathrm{~s}$. The fluorescence transients were recorded from $10 \mu$ s to $5 \mathrm{~s}$ at 12 bit resolution (Strasser et al., 2000). The specific fluxes expressed per reaction centre $(A B S / \mathrm{RC}$; $\left.T R_{0} / \mathrm{RC} ; D I_{0} / \mathrm{RC} ; E T_{0} / \mathrm{RC}\right)$ and phenomenological fluxes per cross section $\left(A B S / C S ; T R_{0} / \mathrm{CS} ; D I_{0} / \mathrm{CS} ; E T_{0} / \mathrm{CS}\right)$ were derived from the theory of energy flux from biomembranes (Sironval et al., 1981) and were calculated using the OJIP test. Absorbance $(A B S)$ referred to the absorption of photons by the chlorophyll molecules in the antenna complex. Part of the absorbed energy was trapped $\left(T R_{0}\right)$ by the reaction centre of PS II $\left(\mathrm{P}_{680}\right)$ while the remainder was dissipated $\left(D I_{0}\right)$ in the form of heat and fluorescence. Of the trapped energy, part of it was converted to reduce energy by electron transport $\left(E T_{0}\right)$ through $\mathrm{Q}_{\mathrm{A}}$ and $\mathrm{Q}_{\mathrm{B}}$ (Strasser et al., 2000). Also determined were the density of reaction centres (RC) per cross section (RC/CS), the maximum efficiency of photosystem II (PS II) $\left(\phi_{P o}=T R_{0} / A B S\right)$, the maximum efficiency of nonphotochemical de-excitation $\left(\phi_{P o}=D I_{0} / A B S\right)$ and the probability that a trapped exciton $\left(\psi_{o}=E T_{0} / T R_{0}\right)$ or that an absorbed photon $\left(\phi_{E o}=E T_{0} / A B S\right)$ moves an electron beyond quinone $\mathrm{A}\left(\mathrm{Q}_{\mathrm{A}}\right)$. The performance index $(P I)$ is defined as the ratio of two structure-function-indexes $(S F I)$. The first, $S F I_{p o}$, responds to structural and functional PS II events leading to electron transport within photosynthesis (Tsmilli-Michael et al., 1998). The second, $S F I_{N o}$, refers to the energy that is dissipated or lost from photosynthetic electron transport (Strasser et al., 1999). It is defined as:

$$
\begin{aligned}
& S F I_{P o(A B S)}=\left(\mathrm{Chl}_{\mathrm{RC}} / \mathrm{Chl}_{\mathrm{tot}}\right) \phi_{P o} \psi_{o} \\
& \text { and } \\
& S F I_{N o(A B S)}=\left[1-\left(\mathrm{Chl}_{\mathrm{RC}} / \mathrm{Chl}_{\mathrm{tot}}\right)\right]\left(1-\phi_{P o}\right)\left(1-\psi_{o}\right),
\end{aligned}
$$

where $\mathrm{Chl}_{\text {tot }}$ is the total $\mathrm{Chl} a$ concentration, and $\mathrm{Chl}_{\text {tot }}=$ $\mathrm{Chl}_{\text {antenna }}+\mathrm{Chl}_{\mathrm{RC}}$.

The combination of both structure-function indexes leads to the expression performance index $(P I)$ either based on absorption of antenna Chls of PS II $\left(P I_{A B S}\right)$, whereby:

$$
P I_{A B S}=S F I_{p o(A B S)} / S F I_{N o(A B S)}=\left\{\left(\mathrm{Chl}_{\mathrm{RC}} / \mathrm{Chl}_{\mathrm{tot}}\right) /\left[1-\left(\mathrm{Chl}_{\mathrm{RC}} /\right.\right.\right.
$$
$\left.\left.\left.\mathrm{Chl}_{\text {tot }}\right)\right]\right\}\left[\phi_{P_{o}} /\left(1-\phi_{P_{o}}\right)\right]\left[\psi_{o} /\left(1-\psi_{o}\right)\right]=\left(\mathrm{Chl}_{\mathrm{RC}} / \mathrm{Chl}_{\text {antenna }}\right)\left[\phi_{P_{o}} /\right.$ $\left.\left(1-\phi_{P_{o}}\right)\right]\left[\psi_{o} /\left(1-\psi_{o}\right)\right]$

or in terms of the expression used the OJIP-test (Srivastava et al. 1999):

$$
P I_{A B S}=(\mathrm{RC} / A B S)\left[\phi_{P_{o}} /\left(1-\phi_{P_{o}}\right)\right]\left[\psi_{o} /\left(1-\psi_{o}\right)\right] .
$$

Experimental design and statistical analysis: The experiment was arranged in a completely randomized design with four species and ten replicates per species. The results were subjected to an analysis of variance (ANOVA) and the means compared by the Tukey $(P \leq 0,05)$. The computer program used to conduct the statistical analyses was SAEG 5.0 (Viçosa - MG).

\section{RESULTS AND DISCUSSION}

Examining the capture and use of energy by the species used in this study, it was found that with increased specific fluxes (per reaction centre), B. macrocalyx and $I$. macrophyla showed greater average values for $A B S / \mathrm{RC}$ and $T R_{0} / \mathrm{RC}$ (figure 1A). Moreover, it was observed that despite the higher values for $A B S / \mathrm{RC}$ and $T R_{0} / \mathrm{RC}, B$. macrocalyx and $I$. macrophyla also exhibited the greatest values of dissipation per reaction centre (figure 1A). The higher values for $D I_{0} / \mathrm{RC}$ found in B. macrocalyx and I. macrophyla indicated a loss of absorbed energy in the form of heat and fluorescence, or the transfer of energy to other systems like nitrate reduction or creation of reactive oxygen species dependent on energy (Strasser et al., 2000). For $E T_{0} / \mathrm{RC}$, B. macrocalyx produced the highest values, which were approximately 33, 37 and $93 \%$ greater than those found in E. cumini, I. macrophyla and S. reticulata, respectively (figure 1A). With regard to the phenomenological fluxes, it was observed that E. cumini and $S$. reticulata exhibited the highest average values of photons absorbed by molecules in the antenna complex $(A B S / C S)$. The highest values for trapped flux $\left(T R_{0} / \mathrm{CS}\right)$ were also found in $E$. cumini and $S$. reticulata (figure 1B). By contrast, the lower values for $T R_{0} / \mathrm{CS}$ in B. macrocalyx and I. macrophyla are evidence of low photochemical efficiency in PS II. This lack of photochemical efficiency resulted in higher dissipation of energy in the form of heat and fluorescence, especially in I. macrophyla, which produced the highest value for $D I_{0}$ / CS (figure 1B). For $E T_{0} / \mathrm{CS}, E$. cumini showed the highest values, which were 79 and $114 \%$ greater than those found for B. macrocalyx and I. macrophyla, respectively. 

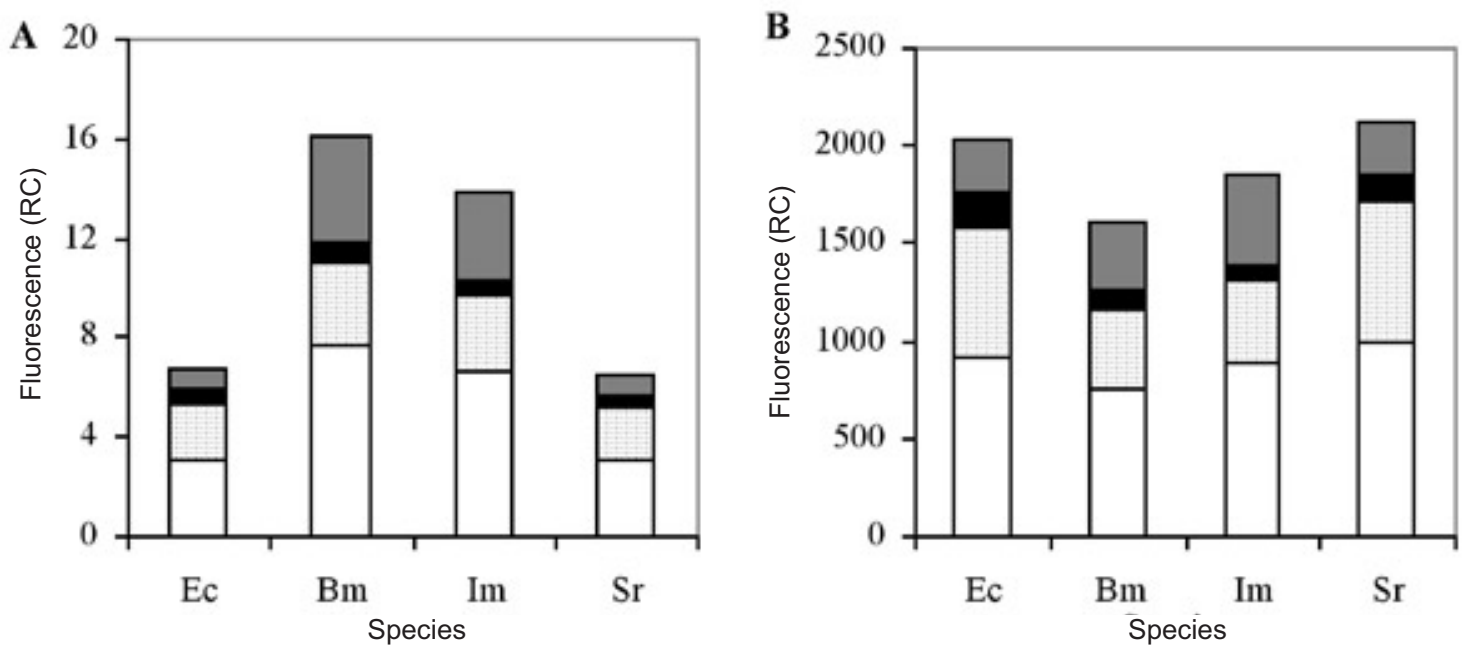

Figure 1. Specific fluxes expressed per reaction centre - CR (A); Phenomenological fluxes expressed per cross section of leaf tissue (CS) in the plants of four tropical species grown on degraded lands in Central Amazonia (B). ( $\square$ ) $A B S$ is the flux of photons absorbed by chlorophyll molecules; $(\square) T R_{0}$ is the energy flux for trapping that is conserved in chemical components; (ם) $E T_{0}$ is the flux of energy that enters into the electron transport chain beyond $\mathrm{Q}_{\mathrm{A}} ;(\square) D I_{0}$ is the flux of energy that is dissipated in the form of heat and fluorescence, or transferred to other systems. Ec $=$ Eugenia cumini; Bm $=$ Bombacopsis macrocalyx $; \mathrm{Im}=$ Iryanthera macrophyla $; \mathrm{Sr}=$ Senna reticulata .

The high values of energy dissipation per reaction centre and consequently per cross section, can be explained by the fact that B. macrocalyx and I. macrophyla had low densities of active reaction centres per cross section (RC/CS), indicating higher susceptibility to high irradiance than the other species in the study. This could have occurred through damage caused to the active reaction centres, resulting in low photochemical efficiency in PS II $\left(\phi_{P o}\right)$ (table 1). The low density of active reaction centres may have also overloaded the working reaction centres in $B$. macrocalyx and $I$. macrophyla as indicated by the higher values of $A B S / \mathrm{RC}$ and $T R_{0} / \mathrm{RC}$. However, in compensation, this could have greatly increased the dissipation of light energy in the form of heat and fluorescence resulting in lower efficiency in PS II (figure $1 \mathrm{~A}$ and table 1). As for the $\phi_{P o}$, it was found the values ranged from 0.48 to 0.73 in the species examined (table 1). Comparing the values of $\phi_{P o}$ with the value $\phi_{\mathrm{Po}}=0.83$, considered as an indicator for plants outside conditions of stress (Bjorkman and Demmig-Adams, 1987), it was found that all the species showed a certain degree of non-chronic photoinhibition, with $S$. reticulata $(12 \%)$ and E. cumini (13 $\%$ ) having smaller degrees of non-chronic photoinhibition than B. macrocalyx (40\%), and I. macrophyla (42\%). The low values for $\phi_{P o}$ found in B. macrocalyx and L. macrophyla could have resulted from inactivity in the reaction centres, which would have favored greater dissipation of energy in

Table 1. Density of active reaction centres per cross section (RC/CS), maximum efficiency of PS II $\left(\phi_{P_{o}}=T R_{0} / A B S\right)$, maximum efficiency of non-photochemical de-excitation $\left(\phi_{D o}=D I_{0} / A B S\right)$, probability that a trapped exciton $\left(\psi_{o}=E T_{0} / T R_{0}\right)$ or that an absorbed photon $\left(\phi_{E o}=E T_{0} / A B S\right)$ moves an electron beyond $\mathrm{Q}_{\mathrm{A}}$, and performance index $\left(P I_{A B S}\right)$ in four tree species growing under high irradiance conditions

\begin{tabular}{lcccc}
\hline Variables & B. macrocalyx & E. cumini & I. macrophyla & S. reticulata \\
\hline $\mathrm{RC} / \mathrm{CS}$ & $121 \pm 67 \mathrm{~b}$ & $303 \pm 44 \mathrm{a}$ & $142 \pm 39 \mathrm{~b}$ & $326 \pm 21 \mathrm{a}$ \\
$T R_{0} / A B S\left(\phi_{P o}\right)$ & $0.50 \pm 0.17 \mathrm{~b}$ & $0.72 \pm 0.06 \mathrm{a}$ & $0.48 \pm 0.17 \mathrm{~b}$ & $0.73 \pm 0.02 \mathrm{a}$ \\
$D I_{0} / A B S\left(\phi_{D o}\right)$ & $0.50 \pm 0.17 \mathrm{a}$ & $0.28 \pm 0.06 \mathrm{~b}$ & $0.52 \pm 0.13 \mathrm{a}$ & $0.27 \pm 0.02 \mathrm{~b}$ \\
$E T_{0} / T R_{0}\left(\psi_{0}\right)$ & $0.25 \pm 0.05 \mathrm{ab}$ & $0.28 \pm 0.07 \mathrm{a}$ & $0.20 \pm 0.07 \mathrm{ab}$ & $0.19 \pm 0.04 \mathrm{~b}$ \\
$E T_{0} / A B S\left(\phi_{E o}\right)$ & $0.12 \pm 0.06 \mathrm{~b}$ & $0.20 \pm 0.06 \mathrm{a}$ & $0.10 \pm 0.05 \mathrm{~b}$ & $0.14 \pm 0.03 \mathrm{ab}$ \\
$P I_{A B S}$ & $0.08 \pm 0.11 \mathrm{~b}$ & $0.40 \pm 0.25 \mathrm{a}$ & $0.06 \pm 0.06 \mathrm{~b}$ & $0.23 \pm 0.10 \mathrm{ab}$ \\
\hline
\end{tabular}

*Mean values \pm standard deviations (SD). Mean values followed by same letters for species are not different at $P \leq 0.05$ using the Tukey test. 
the from of heat and fluorescence as observed in the values for $\phi_{D o}$. Analyzing the efficiency of electron transfer beyond $\mathrm{Q}_{\mathrm{A}}$, it was found that E. cumini showed a higher value for $\psi_{0}$ when compared to $S$. reticulata (table 1 ). This suggests that the probability of excited energy entering in the electron transport chain was greater in E. cumini than in $S$. reticulate, also implying better efficiency in production of reductive power (NADPH). The low values of $\psi_{0}$ in $S$. reticulata also reflect a reduction in the pool of plastoquinone in an oxidized state $(\mathrm{PQ})$ and reoxidation inhibition of $\mathrm{Q}_{\mathrm{A}}^{-}$(Force

\section{Bombacopsis macrocalyx}

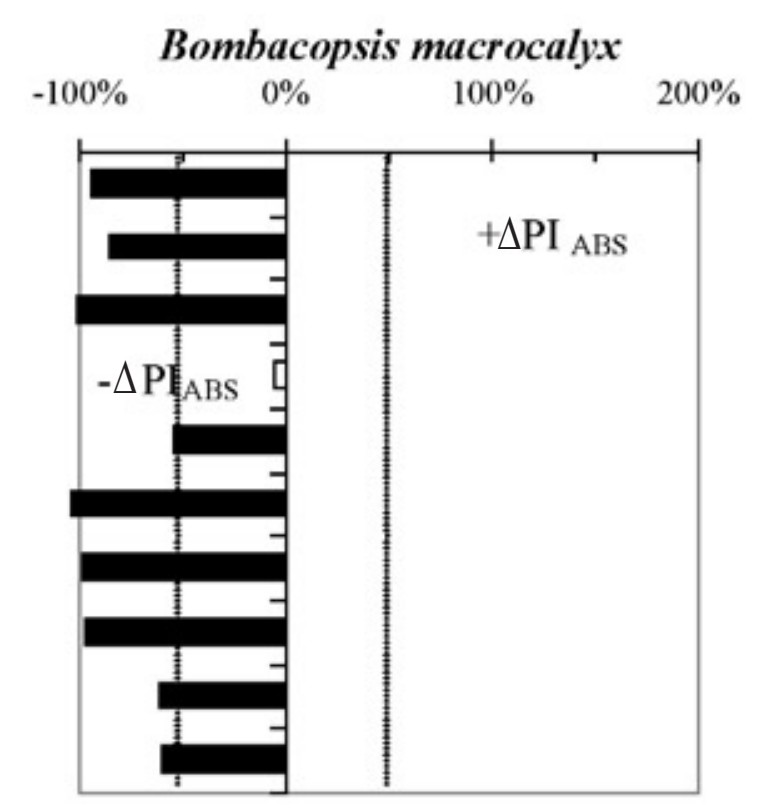

Iryanthera macrophyla

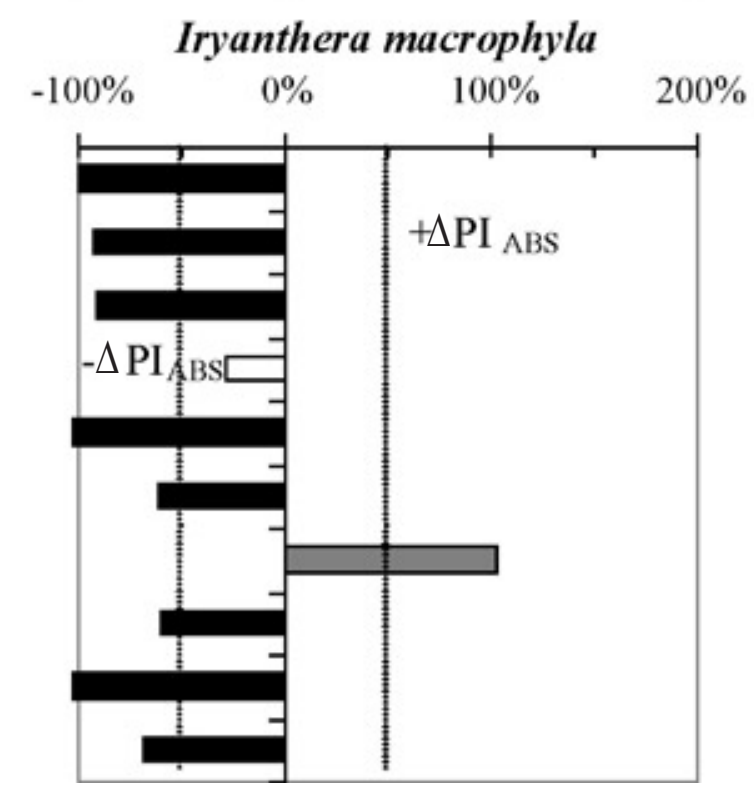

et al., 2003). With regard to $\phi_{E o}, E$. cumini exhibited values approximately 67 and $100 \%$ greater than the values found in B. macrocalyx and I. macrophyla, respectively (table 1). This difference was primarily a result of the efficiency of the energetic flux in PS II as indicated by the lower values for $\mathrm{RC} / \mathrm{CS}$ and $\phi_{P o}$ in B. macrocalyx and I. macrophyla. Comparing the values of $\phi_{E o}$ in E. cumini and S. reticulata, it was found that despite not having statistical significance, a $43 \%$ difference among the values was a reflection of the low values for $\psi_{0}$ observed in $S$. reticulata, which indicates
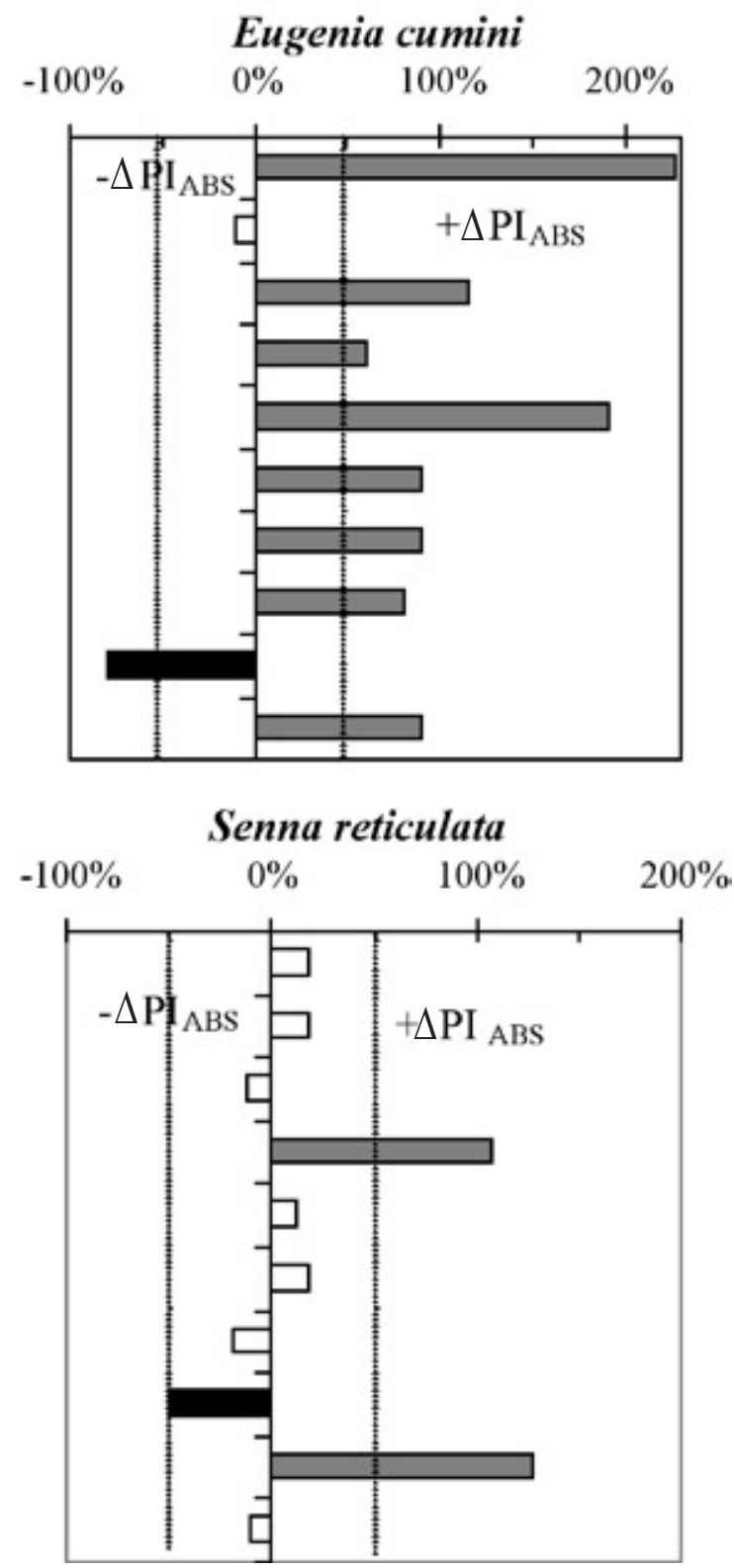

Figure 2. Relative variation of the performance index $\left(P I_{A B S}\right)$ of each tree in relation to the average for $\mathrm{PI}_{\mathrm{ABS}}$ in all of the plants

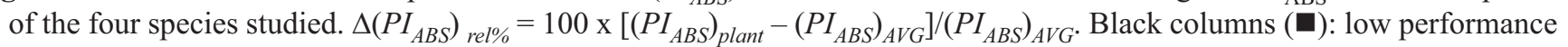
plants $\left(P I_{A B S}<0,5 \times\left(P I_{A B S}\right)_{A V G}\right.$; grey columns $(\square)$ indicate high performance plants $\left(P I_{A B S}>0,5 \times\left(P I_{A B S}\right)_{A V G}\right)$ and; white columns $(\square)$ : average performance plants $P I_{A B S}=\left(P I_{A B S}\right)_{A V G} \pm 50 \%$. 
that E. cumini exhibits strong yield in the transfer of excited energy both among components of PS II as well as in the electron transport chain after $\mathrm{Q}_{\mathrm{A}}$.

Average values for the performance index $\left(P I_{A B S}\right)$ ranged from 0.06 to 0.40 among the species studied with $E$. cumini standing out as having values 5 to 7 times greater than those observed in B. macrocalyx and macrophyla, respectively (table 1). The performance index is a function of $\psi_{0}, \phi_{P O}$, and RC/CS (Srivastava et al., 1999). Among the factors that contributed to the low values of $P I_{A B S}$ in $B$. macrocalyx and $I$. macrophyla, the low density of active reaction centres, high irradiance, and low maximum quantum efficiency in PS II $\left(\phi_{P o}\right)$ were the primary causes, suggesting that a significant part of the energy absorbed was dissipated in the form of heat and fluorescence, and even $\mathrm{Q}_{\mathrm{A}}$. By contrast, when comparing the performance index of E. cumini with that of $S$. reticulata, it was observed that the greatest contribution to performance loss in $S$. reticulata was a low efficiency in the transfer of excited energy after $\mathrm{Q}_{\mathrm{A}}$. These results also suggest that the performance index is a stronger variable for identifying a plant's energy-use efficiency than the maximum photochemical efficiency of PS II alone. This is particularly true because $P I_{A B S}$ allows for wider analysis of not only the relationship between the photon absorption efficiency and the capture of excited energy in PS II, but also the density of active reaction centres and the probability of excited energy moving an electron beyond $\mathrm{Q}_{\mathrm{A}}$. This can be proven by the fact that $E$. cumini (0.72) exhibited values for $F_{v} / F_{m}$ similar to those of $S$. reticulata $(0.73)$ while for $\mathrm{PI}_{\mathrm{ABS}}, E$. cumini (0.40) had an average value $74 \%$ greater than the observed value for $S$. reticulata (0.23). Considering the values of $P I_{A B S}$ for each plant individually, the plants can be separated into three categories that are defined by their performance in optimizing the use of excess irradiance in the photosynthetic processes. These categories are defined as: high performance plants $\left(P I_{A B S}>0,5 \times \mathrm{XI}_{\mathrm{ABS} \text { average }}\right)$, average performance plants $\left(P I_{A B S}=P I_{A B S \text { average }} \pm 50 \%\right)$, and low performance plants $\left(P I_{A B S}<0,5 \mathrm{x} P I_{A B S \text { average }}\right)$ (figure 2$)$. Analyzing the $\mathrm{PI}_{\mathrm{ABS}}$ for each plant, it may be noted that $E$. cumini was the species with the highest number of plants with high performance indexes while I. macrophyla and B. macrocalyx had the highest numbers of low performance plants (figure 2). As for $S$. reticulata, $70 \%$ of its plants fell within the range characterized as average performance (figure 2). These results suggest that the species $E$. cumini and $S$. reticulata show the greatest potential for use in forest plantations when compared with L. macrophyla and B. macrocalyx, since that latter two species generally showed greater probability for low performance in environments of high irradiance.

The relationship between $\log \left(P I_{A B S}\right)$ and $E T_{0} / A B S$ can be considered a typical property of a plant's ability to transform light energy into chemical energy (NADPH), which is subsequently directed into metabolic reactions in the biochemical process of photosynthesis (Hermans et al., 2003). In this respect, the results shown in figure 3 demonstrate that the E. cumini plants exhibited a strong ability to utilize excess irradiance in the environment and transfer it into chemical energy that can be used to reduce $\mathrm{CO}_{2}$ to carbohydrate. This high efficiency is due to the fact that E. cumini plants optimized their use of energy not only for activities related to PS II, but also in electronic transfer processes in the electron transport chain, as can be seen from the high values of $E T_{0} / A B S$ rel. As for $S$. reticulata, it was demonstrated that the processes of transfer in the electron transport chain beyond $\mathrm{Q}_{\mathrm{A}}$ was a limiting factor for the increase of efficiency in the conversion of light energy to chemical energy. By contrast, B. macrocalyx and I. macrophyla showed significant limitations in relation to the transfer of electrons in PS II due to inactivity and increased entropy in reactions centres of PS II, which was provoked by the high dissipation of energy.

In conclusion, considering the performance index, it can be seen that E. cumini was the most effective species with the highest number of high performance plants. By contrast, $B$.

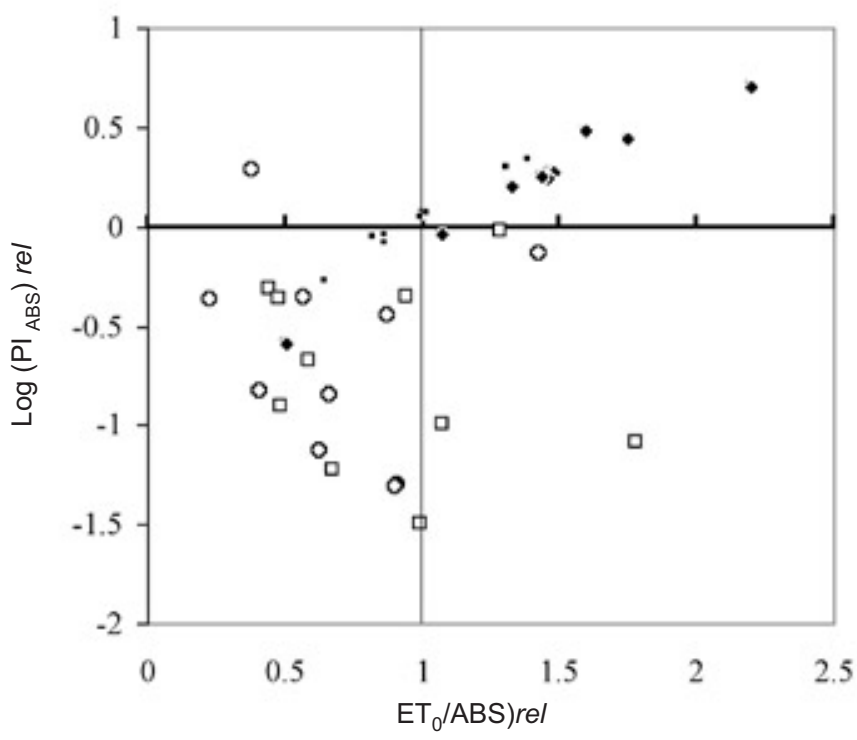

Figure 3. Correlation between the driving force $\left(\log \left(P I_{A B S}\right) \mathrm{rel}\right)$ and the relative yield of electron transport $\left(E T_{0} / A B S\right) r e l$. The filled circles $(\bullet)$ represent Eugenia cumini, empty circles $(\bigcirc)$ represent Iryanthera macrophyla, filled squares (ם) represent Senna reticulate, and empty squares ( $\square$ ) represent Bombacopsis macrocalyx. 
macrocalyx and I. macrophyla exhibited the lowest values for $P I_{A B S}$, mostly due to low efficiency in the transfer of energy in PS II as a result of a decrease in the density of reaction centres. S. reticulata was found to be the species with the highest number of individual plants with a normal $P I_{A B S}$, being limited only by energy transfer in the electron transport chain beyond $\mathrm{Q}_{\mathrm{A}}$. From these results, it is evident that $E$. cumini and $S$. reticulata possess more efficient mechanisms for the use and capture of energy when compared with $B$. macrocalyx and I. macrophyla, suggesting that E. cumini and $S$. reticulata are more suitable for use in forest plantations. Regarding chlorophyll $a$ fluorescence, this technique can be a very efficient tool for the evaluation of the yield of energy in PS II and electron transport chain in environments of high irradiance. The technique can be used not only to identify and select species, but it may also serve to monitor the effects of stress resulting from high irradiance in areas that are in the process of rehabilitation.

Acknowledgements: The authors would like to thank the Ministry of Science and Technology, FINEP/CTPetro, and all the researchers from the Plant Physiology and Biochemistry Laboratory (MCT/INPA) for their support.

\section{REFERENCES}

Bjorkman O, Demmig-Adams B (1987) Photon yield of $\mathrm{O}_{2}$ evolution and chlorophyll fluorescence characteristics at $77 \mathrm{k}$ among vascular plants of diverse origins. Planta 170: 489-504.

Brandão ASP, Rezende GC, Marques RWC (2005) Crescimento agrícola no período 1999-2004, explosão da área plantada com soja e meio ambiente no Brasil. Instituto de Pesquisa Econômica Aplicada - IPEA. Rio de Janeiro-RJ. 21p.

Clark AJ, Landolt W, Bucher JB, Strasser RJ (2000) Beech (Fagus sylvatica) response ozone exposure assessed with a chlorophyll $a$ fluorescence performance. Environ. Pollut. 109:501-507.

Fearnside PM (1999) Biodiversity as an environmental service in Brazil's Amazonian forest: risks, value and conservation. Environ. Conserv. 26:305-321.

Fearnside PM (2002) Modelos de uso da terra predominante na Amazônia: Um desafio para a sustentabilidade. In: Amazônia: Uma perspectiva multidisciplinar. Centro de Ciências do Meio Ambiente. Editora da Universidade do Amazonas (EDUA), Manaus/AM. p.103-154.
Force L, Critchley C, Rensen JJS (2003) New fluorescence parameters for monitoring photosynthesis in plants. Photosynth. Res. 78:17-33.

Gonçalves JFC, Marenco RA, Vieira G (2001) Concentration of photosynthetic pigments and chlorophyll fluorescence of mahogany and tonka bean under two light environments. Braz. J. Plant Physiol. 13: 149-157.

Hermans C, Smeyers M, Rodriguez RM, Eyletters M, Strasser RJ, Delhaye JP (2003) Quality assessment of urban trees: A comparative study of physiological characterization, airborne imaging and on site fluorescence monitoring by the OJIP-test. J. Plant Physiol. 160:81-90.

Laurance WF, Albernaz AKM, Costa C (2002) Is deforestation accelerating in Brazilian Amazon? Environ. Conserv. 28: 305-311.

Maxwell K, Johnson GN (2000) Chlorophyll fluorescence a practical guide. J. Exp. Bot. 51:659-668.

Misra AN, Srivastava A, Strasser RJ (2001) Utilization of fast chlorophyll $a$ technique in assessing the salt/ion sensitivity of mung bean and brassica seedlings. J. Plant Physiol. 158: 1173-1181.

Parrotta JA, Turnbull JW, Jones N (1997) Catalyzing native forest regeneration on degraded tropical lands. Forest Ecol. Managem. 99:1-7.

Parrotta JA, Knowles OH (1999) Restoration of tropical moist forest on bauxite mined lands in Brazilian Amazon. Restor. Ecol. 7:103-116.

Sironval C, Strasser RJ, Brouers M (1981) Equivalence entre la theorie des flux et la theorie des relations entre proportions de pigments pour la description de la repartition de lenergie lumineuse absorbee par les membranas photoactives. Bull. Acad. R. Belg. 67:248-259.

Srivastava A, Strasser RJ, Govindjee (1999) Greening of peas: parallel measurements of $77 \mathrm{~K}$ emission spectra, OJIP chlorophyll $a$ fluorescence transient, period four oscillation of the initial fluorescence level, delayed light emission, and P700. Photosynthetica 37:365-392.

Strasser RJ, Srivastava A, Tsimilli-Michael M (1999) Screening the vitality and photosynthetic activity of plants by fluorescence transient. In: Behl RK, Punia MS, Lather BPS (eds), Crop Improvement for Food Security, pp.79126. Hisar, SSARM.

Strasser RJ, Srivastava A, Tsimilli-Michael M (2000) The fluorescence transient as a tool to characterize and screen photosynthetic samples. In: Yunus M, Pathre U, Mohanty P. (eds), Probing Photosynthesis: Mechanisms, Regulation and Adaptation, pp.445-483. Taylor \& Francis, London, UK.

Tsimili-Michael M, Pêcheux M, Strasser RJ (1998) Vitality and stress adaptation of the symbionts of coral reef and temperate foraminifers probed in hospite by the fluorescence kinetcs PJIP. Arch. Sci. Genève 51:205-240. 